Western University

Scholarship@Western

Chemistry Publications

Chemistry Department

Winter 2-6-2017

\title{
Phosphonium-Functionalized Polymer Micelles with Intrinsic Antibacterial Activity
}

Benjamin Hisey

Western University, bhisey@uwo.ca

Paul J. Ragogna

The University of Western Ontario

Elizabeth Gillies

Western University, egillie@uwo.ca

Follow this and additional works at: https://ir.lib.uwo.ca/chempub

Part of the Polymer Chemistry Commons

Citation of this paper:

Hisey, Benjamin; Ragogna, Paul J.; and Gillies, Elizabeth, "Phosphonium-Functionalized Polymer Micelles with Intrinsic Antibacterial Activity" (2017). Chemistry Publications. 95.

https://ir.lib.uwo.ca/chempub/95 


\title{
Phosphonium-functionalized polymer micelles with intrinsic
}

\section{antibacterial activity}

Benjamin Hisey", Paul J. Ragogna ${ }^{\#}$, and Elizabeth R. Gillies ${ }^{\# *}$

"Department of Chemistry and Centre for Advanced Materials and Biomaterials Research, The University of Western Ontario, 1151 Richmond St., London, Canada N6A 5B7

${ }^{\$}$ Department of Chemical and Biochemical Engineering, The University of Western Ontario, 1151 Richmond St., London, Canada N6A 5B9

*Author to whom correspondence should be addressed (Email: egillie@uwo.ca)

\begin{abstract}
New approaches to treat bacterial infections are badly needed to address the increasing problem of antibiotic-resistance. This study explores phosphonium-functionalized block copolymer micelles as intrinsically antibacterial polymer assemblies. Phosphonium cations with varying alkyl lengths were conjugated to the terminus of a poly(ethylene oxide)-polycaprolactone block copolymer and the phosphonium-functionalized block copolymers were self-assembled to form micelles in aqueous solution. The size, morphology, and $\zeta$-potential of the assemblies were studied and their abilities to kill Escherichia coli and Staphylococcus aureus were evaluated. It was found that the minimum bactericidal concentration depended on the phosphonium alkyl chain length and different trends were observed for Gram-negative and Gram-positive bacteria. The most active assemblies exhibited no hemolysis of red blood cells above the bactericidal
\end{abstract}


concentrations, indicating that they can selectively disrupt the membranes of bacteria.

Furthermore, it was possible to encapsulate and release the antibiotic tetracycline using the assemblies, providing a potential multi-mechanistic approach to bacterial killing.

\section{Keywords}

Phosphonium, antibacterial, micelles, antibiotic, self-assembly

\section{Introduction}

Polymeric nanocarriers, self-assembled nanoscopic materials with domains of different hydrophilicity, have been extensively investigated due to their abilities to encapsulate biomedically relevant cargo and to provide a chemically tunable platform. ${ }^{1-4}$ Common nanocarrier morphologies are spherical micelles ${ }^{5}$, cylindrical micelles, ${ }^{6,7}$ bilayer structures (e.g. vesicles $)^{8}$ and in some circumstances more complex architectures that can be obtained using unconventional polymers or intermolecular interactions. ${ }^{9}$ Amphiphilic block copolymers are often the structural components of polymeric nanocarriers, due to the control they provide over the morphology and the well-established chemistry used to synthesize and functionalize them. By encapsulating hydrophobic compounds into the hydrophobic domains of nanomaterials, these water-insoluble molecules can be dispersed in aqueous solutions. ${ }^{4,10,11}$ Block copolymer nanocarriers have been and continue to be investigated for the delivery of a large variety of compounds including small molecule drugs, therapeutic nucleic acids, imaging contrast agents, and antibacterial compounds. ${ }^{1,4,12}$

An increase in the occurrence of pernicious antibiotic resistant bacteria is currently motivating a search for novel ways of combating bacterial infections. The World Health Organization warns that in order to avoid a return to the "pre-antibiotic" age, researchers and 
health professionals need to employ new and varied antibiotic treatments of bacterial infections. ${ }^{13}$ The ability to incorporate hydrophobic antibacterial compounds into aqueous dispersible nanocarriers allows for increased availability of the drugs at the site of infection. ${ }^{14}$ The use of nanocarriers has allowed researchers to utilize traditional antibacterial compounds with improved efficacy. For example, intracellular bacterial infections are often resistant to antibacterial treatment due to the localization of the bacteria in the eukaryotic cells. Maya and coworkers were able to target intracellular Staphylococcus aureus (S. aureus) by encapsulating tetracycline in chitosan nanoparticles. ${ }^{15} \mathrm{Li}$ et al. demonstrated the encapsulation of antibacterial agents into polymer vesicles that enzymatically degraded in the presence of target bacteria to deliver the antibacterial cargo. ${ }^{16}$ Furthermore, Liu and coworkers have recently demonstrated the ability of triclosan-loaded micelles to penetrate into biofilms and to kill the $S$. aureus residing in the biofilms with greater efficacy than free triclosan. ${ }^{17}$ There are many other examples that demonstrate the increase in desirable properties that can be achieved by loading antibacterial small molecules into nanocarrier systems. ${ }^{12,18,19}$ This approach may also allow for the use new poorly water-soluble antibacterial compounds in the combat of antibacterial resistance.

Far fewer examples exist of nanocarriers with inherently antibacterial units. This is somewhat surprising given the extensive research that has been performed on incorporating functionality into nanocarrier design. ${ }^{2,20}$ The incorporation of silver nanoparticles ${ }^{21-23}$ and/or polymers such as chitosan ${ }^{24,25}$ or other polyammonium cations, ${ }^{26-29,}$ have been explored as an approach for imparting antibacterial activity to nanocarriers. Previously unexplored is the use of phosphonium cations to impart antibacterial activity to polymeric nanocarriers. Phosphonium cations, like ammonium cations, are thought to interact with the negatively charged structural biopolymers and phospholipids on the outer surfaces of bacteria cell walls, leading to penetration 
of the cell wall, ultimately resulting in cell death. ${ }^{29-31}$ Gram-positive bacteria such as S. aureus have teichoic acid polymers on the cell wall that confer a negative charge and Gram-negative bacteria such as Escherichia coli (E. coli) have lipopolyssacharides that are responsible for the negative charge of the cell surface. Previous research has demonstrated that phosphonium salts as well as their corresponding polymers exhibit improved antibacterial efficacy compared to analogous ammonium compounds. ${ }^{32-34}$ This can arise from the differences in charge distribution between the larger phosphonium cation and smaller ammonium cation. In this context, we recently demonstrated the efficacy of surfaces and semi-interpenetrating networks containing phosphonium cations against Gram-positive and Gram-negative bacteria. ${ }^{35,36}$

Here we explore the synthesis and self-assembly of phosphonium end-capped poly(ethylene oxide)-block-polycaprolactone (PEO-b-PCL) copolymers. To the best of our knowledge, this represents the first example of phosphonium-functionalized block copolymer assemblies in aqueous solution. We also demonstrate the antibacterial properties of the assemblies against $S$. aureus and E. coli. Furthermore, it is shown that the antibiotic tetracycline can be incorporated into the micelles, potentially providing orthogonal modes of action, where the traditional antibiotic targets specific pathways in bacteria while the phosphonium cation provides membrane disruption (Figure 1). While work exists demonstrating the benefit of combining antibacterial nanoparticles with traditional antibacterial small molecules ${ }^{25,37}$ the deliberate encapsulation of a traditional antibacterial agent within an intrinsically antibacterial polymeric nanocarrier has not been reported. 


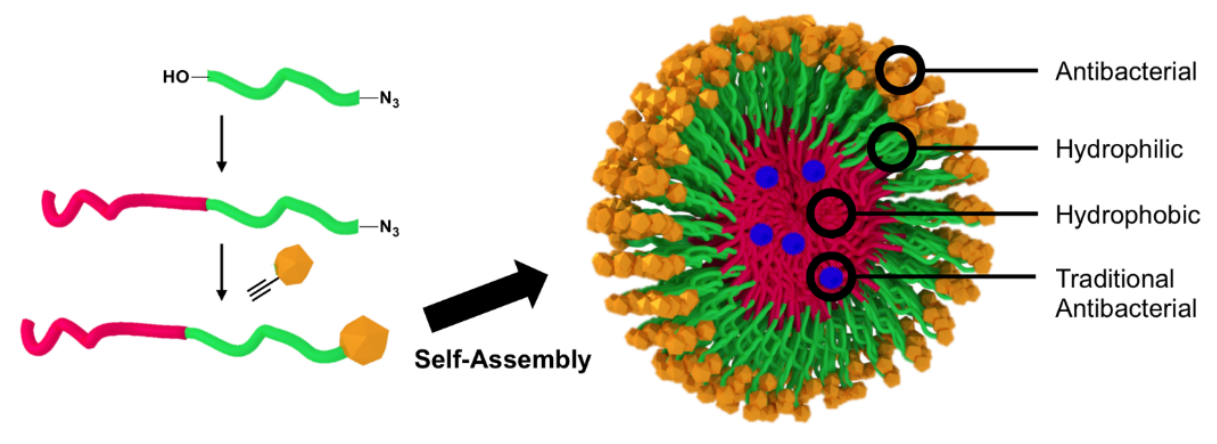

Figure 1. Schematic illustrating a phosphonium-functionalized micelle loaded with antibiotic.

\section{Experimental}

\section{General procedures and materials}

Methoxy and azide-terminated block copolymers (MeO-BCP and $\mathbf{N}_{\mathbf{3}}-\mathbf{B C P}$ respectively) were prepared as previously reported ${ }^{38}$ and the characterization data for the specific batches used in the current work are included in the supporting information. Briefly, they were prepared by ringopening polymerizations of freshly distilled $\varepsilon$-caprolactone in dry toluene initiated by PEO monomethyl ether (MeO-PEO) or PEO monoazide ( $\mathbf{N}_{\mathbf{3}}$-PEO). Methanesulfonic acid was used as a catalyst, and the product was obtained by precipitation into cold hexanes. Solvents were dried using an MBraun Solvent Purification System. Dried solvent was collected under vacuum in a flame-dried Straus flask and stored over $4 \AA$ molecular sieves. Purified water was obtained using a Barnstead ${ }^{\mathrm{TM}}$ EASYPure ${ }^{\circledR}$ II ultra pure water system (ThermoFisher Scientific). Nuclear Magnetic Resonance (NMR) spectroscopy was conducted on a Varian INOVA $400 \mathrm{MHz}$ spectrometer (Agilent Technologies, Santa Clara, CA; ${ }^{1} \mathrm{H} 400 \mathrm{MHz},{ }^{31} \mathrm{P}\left\{{ }^{1} \mathrm{H}\right\} 162 \mathrm{MHz},{ }^{13} \mathrm{C}\left\{{ }^{1} \mathrm{H}\right\}$ $100 \mathrm{MHz}$ ) unless otherwise noted. All ${ }^{1} \mathrm{H}$ NMR spectra were referenced relative to the residual solvent peak $\left(\mathrm{CHCl}_{3} ;{ }^{1} \mathrm{H} \delta=7.27\right)$. The chemical shifts for ${ }^{31} \mathrm{P}\left\{{ }^{1} \mathrm{H}\right\}$ NMR spectroscopy were referenced using an external standard $\left(85 \% \mathrm{H}_{3} \mathrm{PO}_{4} ; \delta_{\mathrm{P}}=0\right)$. All ${ }^{13} \mathrm{C}\left\{{ }^{1} \mathrm{H}\right\}$ NMR spectra were referenced relative to the residual solvent peak $\left(\mathrm{CDCl}_{3} ;{ }^{13} \mathrm{C} \delta=77.0\right)$. Infrared (IR) spectra were obtained using a Bruker Tensor 27 spectrometer using attenuated total internal reflectance mode 
(ATR) on a ZnSe crystal. High Resolution Mass spectrometry (HRMS) were obtained on a Finnigan MAT 8400 mass spectrometer using electron impact ionization. Dynamic light scattering (DLS) and $\zeta$-potential measurements were performed on a Zetsizer Nano ZS from Malvern Instruments equipped with a $633 \mathrm{~nm}$ laser. A polymer concentration of $\sim 0.1 \mathrm{mg} / \mathrm{mL}$ of polymer were used in DLS measurements. Ultraviolet-visible (UV-vis) spectroscopy was performed using a Varian Cary 300 Bio UV-visible spectrophotometer. The size exclusion chromatography (SEC) instrument was equipped with a Viscotek GPC Max VE2001 solvent module (Malvern Instruments Ltd., Malvern, UK). Samples were analyzed using the Viscotek VE3580 RI detector operating at $30^{\circ} \mathrm{C}$. The separation technique employed two Agilent Polypore $(300 \times 7.5 \mathrm{~mm})$ columns connected in series and to a Polypore guard column $(50 \times 7.5$ mm) (Agilent Technologies). Samples were dissolved in tetrahydrofuran (THF) (glass distilled grade) at a concentration of approximately $5 \mathrm{mg} / \mathrm{mL}$, filtered through $0.22 \mu \mathrm{m}$ syringe filters, and then injected using a $100 \mu \mathrm{L}$ loop. The THF eluent was filtered and eluted at $1 \mathrm{~mL} / \mathrm{min}$ for a total of 30 min. The instrument was calibrated with PEO standards. Dialysis was performed using Spectra/Por ${ }^{\circledR} 6$ pre-wetted dialysis tubing (Spectrum Laboratories Inc.).

\section{Synthesis of tri-n-butyl(1-pentynyl)phosphonium chloride (Bu, P-yne)}

Tributylphosphine (5.00 g, $24.5 \mathrm{mmol}, 1.0$ equiv.) was dissolved in dry $\mathrm{CH}_{3} \mathrm{CN}$ in a pressure tube inside a glovebox. 5-Chloro-1-pentyne ( $2.80 \mathrm{~g}, 27.3 \mathrm{mmol}, 1.1$ equiv.) was then added dropwise to the stirring phosphine solution. The pressure tube was sealed and then heated at 100 ${ }^{\circ} \mathrm{C}$. The reaction was monitored by ${ }^{31} \mathrm{P}\left\{{ }^{1} \mathrm{H}\right\}$ NMR spectroscopy. Upon exhaustion of the tributyl phosphine the volatile components were removed in vacuo. The crude product was dissolved in $\mathrm{CH}_{2} \mathrm{Cl}_{2}$ and precipitated into a rapidly stirring solution of cold hexanes $\left(0^{\circ} \mathrm{C}\right)$ to afford an off- 
white powder. The product was recovered by vacuum filtration. Yield $=6.31 \mathrm{~g}, 84 \% .{ }^{1} \mathrm{H}$ NMR $\left(400 \mathrm{MHz}, \mathrm{CDCl}_{3}\right): \delta=2.70-2.68(\mathrm{~m}, 2 \mathrm{H}), 2.53-2.42(\mathrm{~m}, 8 \mathrm{H}), 2.05\left(\mathrm{t},{ }^{4} \mathrm{~J}(\mathrm{H}, \mathrm{H})=2.73 \mathrm{~Hz}\right.$, 1H), $1.90-1.79(\mathrm{~m}, 2 \mathrm{H}), 1.61-1.47(\mathrm{~m}, 12 \mathrm{H}), 0.97\left(\mathrm{t},{ }^{3} \mathrm{~J}(\mathrm{H}, \mathrm{H})=7.23 \mathrm{~Hz}, 9 \mathrm{H}\right) .{ }^{13} \mathrm{C}\left\{{ }^{1} \mathrm{H}\right\}$ $\left(100.52 \mathrm{MHz}, \mathrm{CDCl}_{3}\right): \delta=82.0,70.5,23.9\left(\mathrm{~d},{ }^{3} \mathrm{~J}(\mathrm{P}, \mathrm{C})=15.3 \mathrm{~Hz}\right), 23.7\left(\mathrm{~d},{ }^{2} \mathrm{~J}(\mathrm{P}, \mathrm{C})=5.3 \mathrm{~Hz}\right)$, $21.0\left(\mathrm{~d},{ }^{2} \mathrm{~J}(\mathrm{P}, \mathrm{C})=3.8 \mathrm{~Hz}\right), 19.4\left(\mathrm{~d},{ }^{3} \mathrm{~J}(\mathrm{P}, \mathrm{C})=16.8 \mathrm{~Hz}\right), 19.0\left(\mathrm{~d},{ }^{1} \mathrm{~J}(\mathrm{P}, \mathrm{C})=47.5 \mathrm{~Hz}\right), 18.2(\mathrm{~d}$, $\left.{ }^{1} \mathrm{~J}(\mathrm{P}, \mathrm{C})=49.0 \mathrm{~Hz}\right), 13.4 .{ }^{31} \mathrm{P}\left\{{ }^{1} \mathrm{H}\right\} \mathrm{NMR}\left(161.82 \mathrm{MHz}, \mathrm{CDCl}_{3}\right): \delta=34$. ATR-IR: $2105 \mathrm{~cm}^{-1}(\mathrm{w}$, $\mathrm{C} \equiv \mathrm{C}-\mathrm{H}), 2960 \mathrm{~cm}^{-1}(\mathrm{~s}, \mathrm{CH})$. HRMS calculated for $\mathrm{C}_{17} \mathrm{H}_{34} \mathrm{P}[\mathrm{M}]^{+}: 269.2398$; Found: 269.2400 .

\section{Synthesis of triethyl(1-pentynyl)phosphonium chloride (Et $\left.\boldsymbol{P}_{\mathbf{P}} \mathbf{y} \boldsymbol{\mathbf { e }}\right)$}

The same procedure described above for the synthesis of $\boldsymbol{B} \boldsymbol{u}_{3} \boldsymbol{P}-\boldsymbol{y} \boldsymbol{n} \boldsymbol{e}$ was used except that triethylphosphine was used as the starting material. The product was obtained as a light brown powder. Yield $=80 \% .{ }^{1} \mathrm{H}$ NMR $\left(400 \mathrm{MHz}, \mathrm{CDCl}_{3}\right): \delta=2.62-2.47(\mathrm{~m}, 8 \mathrm{H}), 2.41\left(\mathrm{ddt},{ }^{3} \mathrm{~J}(\mathrm{H}, \mathrm{H})\right.$ $\left.=3.6 \mathrm{~Hz},{ }^{4} \mathrm{~J}(\mathrm{H}, \mathrm{H})=2.7 \mathrm{~Hz},{ }^{4} \mathrm{~J}(\mathrm{P}, \mathrm{H})=0.8 \mathrm{~Hz}, 2 \mathrm{H}\right), 2.02\left(\mathrm{t},{ }^{4} \mathrm{~J}(\mathrm{H}, \mathrm{H})=2.7 \mathrm{~Hz}, 1 \mathrm{H}\right), 1.87-1.77$ $(\mathrm{m}, 2 \mathrm{H}), 1.28\left(\mathrm{dt},{ }^{3} \mathrm{~J}(\mathrm{H}, \mathrm{H})=7.6 \mathrm{~Hz},{ }^{3} \mathrm{~J}(\mathrm{P}, \mathrm{H})=18.0 \mathrm{~Hz}, 9 \mathrm{H}\right) .{ }^{13} \mathrm{C}\left\{{ }^{1} \mathrm{H}\right\}\left(100.52 \mathrm{MHz}, \mathrm{CDCl}_{3}\right): \delta=$ 82.1, 70.9, $21.0\left(\mathrm{~d},{ }^{2} \mathrm{~J}(\mathrm{P}, \mathrm{C})=3.7 \mathrm{~Hz}\right), 19.6\left(\mathrm{~d},{ }^{3} \mathrm{~J}(\mathrm{P}, \mathrm{C})=16.5 \mathrm{~Hz}\right), 17.1\left(\mathrm{~d},{ }^{1} \mathrm{~J}(\mathrm{P}, \mathrm{C})=48.6 \mathrm{~Hz}\right)$, $12.5\left(\mathrm{~d},{ }^{1} \mathrm{~J}(\mathrm{P}, \mathrm{C})=48.7 \mathrm{~Hz}\right), 6.2\left(\mathrm{~d},{ }^{2} \mathrm{~J}(\mathrm{P}, \mathrm{C})=5.5 \mathrm{~Hz}\right) .{ }^{31} \mathrm{P}\left\{{ }^{1} \mathrm{H}\right\}$ NMR $\left(161.82 \mathrm{MHz}, \mathrm{CDCl}_{3}\right): \delta=$ 39. ATR-IR: $2105 \mathrm{~cm}^{-1}$ (w, C $\left.\equiv C-H\right), 2960 \mathrm{~cm}^{-1}$ (s, CH). HRMS calculated for $\mathrm{C}_{11} \mathrm{H}_{21} \mathrm{P}[\mathrm{M}]^{+}$: 184.1381; Found: 184.1379.

\section{Synthesis of tri-n-octyl(1-pentynyl)phosphonium chloride (Oct $\left.\boldsymbol{P}_{3}-\mathbf{y n e}\right)$}

Tri-n-octylphosphine (1.00 g, $2.70 \mathrm{mmol}, 1.0$ equiv.) was dissolved in dry dioxane in a pressure tube inside a glovebox. $5 \mathrm{mg}$ of NaI was added to the reaction mixture. 5-Chloro-1-pentyne ( $0.300 \mathrm{~g}, 2.92 \mathrm{mmol}, 1.1$ equiv.) was then added dropwise to the stirring phosphine solution. The 
pressure tube was sealed and then heated at $100{ }^{\circ} \mathrm{C}$. The reaction was monitored by ${ }^{31} \mathrm{P}\left\{{ }^{1} \mathrm{H}\right\}$ NMR spectroscopy. At approximately $50 \%$ conversion of the starting phosphine, the excess phosphine, 5-chloropentyne and solvent were removed in vacuo. The resulting colourless oil was washed twice with excess hexanes. The crude product was purified on a silica gel column using 1:1 $\mathrm{CH}_{2} \mathrm{Cl}_{2}: \mathrm{MeOH}$ as the eluent. Fractions were checked for purity by ${ }^{31} \mathrm{P}\left\{{ }^{1} \mathrm{H}\right\} \mathrm{NMR}$ spectroscopy, pure fractions were combined and the solvent was removed in vacuo to provide a light brown viscous oil. Yield $=12 \% .{ }^{1} \mathrm{H}$ NMR $\left(400 \mathrm{MHz}, \mathrm{CDCl}_{3}\right): \delta=2.70-2.57(\mathrm{~m}, 2 \mathrm{H})$, $2.44-2.34(\mathrm{~m}, 8 \mathrm{H}), 2.00\left(\mathrm{t},{ }^{4} \mathrm{~J}(\mathrm{H}, \mathrm{H})=2.6 \mathrm{~Hz}, 1 \mathrm{H}\right), 1.84-1.76(\mathrm{~m}, 2 \mathrm{H}), 1.54-1.41(\mathrm{~m}, 12 \mathrm{H})$, $1.27-1.22(\mathrm{~m}, 24 \mathrm{H}), 0.83\left(\mathrm{t},{ }^{3} \mathrm{~J}(\mathrm{H}, \mathrm{H})=6.8 \mathrm{~Hz}, 9 \mathrm{H}\right) .{ }^{13} \mathrm{C}\left\{{ }^{1} \mathrm{H}\right\}\left(100.52 \mathrm{MHz}, \mathrm{CDCl}_{3}\right): \delta=81.9$, 70.4, 31.5, $30.7\left(\mathrm{~d},{ }^{1} \mathrm{~J}(\mathrm{P}, \mathrm{C})=14.1 \mathrm{~Hz}\right), 28.8,22.4,21.7\left(\mathrm{~d},{ }^{3} \mathrm{~J}(\mathrm{P}, \mathrm{C})=4.0 \mathrm{~Hz}\right), 21.0\left(\mathrm{~d},{ }^{3} \mathrm{~J}(\mathrm{P}, \mathrm{C})=\right.$ $4.0 \mathrm{~Hz}), 19.3\left(\mathrm{~d},{ }^{1} \mathrm{~J}(\mathrm{P}, \mathrm{C})=17.1 \mathrm{~Hz}\right), 19.2\left(\mathrm{~d},{ }^{2} \mathrm{~J}(\mathrm{P}, \mathrm{C})=46.2 \mathrm{~Hz}\right), 18.2\left(\mathrm{~d},{ }^{2} \mathrm{~J}(\mathrm{C}, \mathrm{H})=49.2 \mathrm{~Hz}\right)$, $13.9\left(\mathrm{~s}, \mathrm{CH}_{3}\right) .{ }^{31} \mathrm{P}\left\{{ }^{1} \mathrm{H}\right\}$ NMR $\left(161.82 \mathrm{MHz}, \mathrm{CDCl}_{3}\right): \delta=33.9$. ATR-IR: $1460 \mathrm{~cm}^{-1}\left(\mathrm{~m}, \mathrm{P}-\mathrm{C}_{\mathrm{n}} \mathrm{H}_{\mathrm{m}}\right)$, $2120 \mathrm{~cm}^{-1}$ (w, C $\left.\equiv \mathrm{C}-\mathrm{H}\right), 2920 \mathrm{~cm}^{-1}$ (s, CH). HRMS calculated for $\mathrm{C}_{29} \mathrm{H}_{58} \mathrm{P}[\mathrm{M}]^{+}:$: 437.4276; Found: 437.4267.

\section{Synthesis of $\mathbf{A l k}_{3} \boldsymbol{P}-\boldsymbol{B C} \boldsymbol{P}$}

$\mathbf{N}_{3}$-BCP (100 mg, $21 \mu \mathrm{mol}, 1$ equiv.) was suspended in purified water $(2 \mathrm{~mL})$ with stirring. The trialkyl(1-pentynyl)phosphonium chloride ( $42 \mu \mathrm{mol}, 2.0$ equiv) as a solution in THF $(0.5 \mathrm{~mL})$, and $\mathrm{Cu}(\mathrm{II}) \mathrm{Cl}_{2}$ (4 mg, $23 \mu \mathrm{mol}, 1$ equiv.) were added. A $50 \mathrm{mM}$ aqueous solution of sodium ascorbate ( $2 \mathrm{~mL}, 210 \mu \mathrm{mol}, 10$ equiv.) was added with rapid stirring and the reaction flask was sealed. After 18 hours, the reaction mixture was dialyzed using a $10 \mathrm{~kg} / \mathrm{mol}$ molecular weight cut-off (MWCO) membrane first against $1 \mathrm{~L}$ of a $0.5 \mathrm{mM}$ aqueous $\mathrm{NaCl}$ solution for 18 hours, 
then against $1 \mathrm{~L}$ of purified water for 12 hours twice. The sample was then lyophilized to obtain the phosphonium-functionalized polymer as a white powder in approximately quantitative yield. Et t $_{3}$-BCP: ${ }^{1} \mathrm{H}$ NMR (400 MHz, $\left.\mathrm{CDCl}_{3}\right): 7.70(\mathrm{~s}, 1 \mathrm{H}), 4.50\left(\mathrm{t},{ }^{3} \mathrm{~J}(\mathrm{H}, \mathrm{H})=4.9 \mathrm{~Hz}, 2 \mathrm{H}\right), 4.02(\mathrm{t}$, $\left.{ }^{3} \mathrm{~J}(\mathrm{H}, \mathrm{H})=6.6 \mathrm{~Hz}, 52 \mathrm{H}\right), 3.60(\mathrm{~m}, 180 \mathrm{H}), 2.90\left(\mathrm{t},{ }^{3} \mathrm{~J}(\mathrm{H}, \mathrm{H})=6.4 \mathrm{~Hz}, 2 \mathrm{H}\right), 2.49\left(\mathrm{dq},{ }^{2} \mathrm{~J}(\mathrm{H}, \mathrm{P})=13.0\right.$ $\left.\mathrm{Hz},{ }^{3} \mathrm{~J}(\mathrm{H}, \mathrm{H})=8 \mathrm{~Hz}, 6 \mathrm{H}\right) ; 2.29\left(\mathrm{t},{ }^{3} \mathrm{~J}(\mathrm{H}, \mathrm{H})=7.6 \mathrm{~Hz}, 52 \mathrm{H}\right), 1.66-1.56(\mathrm{~m}, 104 \mathrm{H}), 1.40-1.30(\mathrm{~m}$, $52 \mathrm{H}), 1.25\left(\mathrm{dt},{ }^{3} \mathrm{~J}(\mathrm{H}, \mathrm{P})=18.0 \mathrm{~Hz},{ }^{3} \mathrm{~J}(\mathrm{H}, \mathrm{H})=7.6 \mathrm{~Hz}, 9 \mathrm{H}\right) .{ }^{31} \mathrm{P}\left\{{ }^{1} \mathrm{H}\right\} \mathrm{NMR}\left(161.82 \mathrm{MHz}, \mathrm{CDCl}_{3}\right)$ : $\delta=38.7$. ATR-IR: $1105 \mathrm{~cm}^{-1}\left(\mathrm{~m}, \mathrm{CH}_{2}-\mathrm{O}-\mathrm{CH}_{2}\right) ; 1190 \mathrm{~cm}^{-1}(\mathrm{~m}, \underline{O-C}=\mathrm{O}) ; 1720 \mathrm{~cm}^{-1}(\mathrm{~s}, \mathrm{C}=\mathrm{O})$; $2800-2900 \mathrm{~cm}^{-1}(\mathrm{~m}, \mathrm{C}-\mathrm{H})$.

Bu 3 P-BCP: ${ }^{1} \mathrm{H}$ NMR (400 MHz, $\left.\mathrm{CDCl}_{3}\right): \delta=7.72(\mathrm{~s}, 1 \mathrm{H}) ; 4.50\left(\mathrm{t},{ }^{3} \mathrm{~J}(\mathrm{H}, \mathrm{H})=5.2 \mathrm{~Hz}, 2 \mathrm{H}\right), 4.03$ $\left(\mathrm{t},{ }^{3} \mathrm{~J}(\mathrm{H}, \mathrm{H})=6.6 \mathrm{~Hz}, 52 \mathrm{H}\right), 3.61(\mathrm{~m}, 180 \mathrm{H}), 2.90(\mathrm{~m}, 2 \mathrm{H}), 2.65(\mathrm{~m}, 2 \mathrm{H}), 2.37(\mathrm{~m}, 8 \mathrm{H}), 2.27(\mathrm{t}$, $\left.{ }^{3} \mathrm{~J}(\mathrm{H}, \mathrm{H})=7.6 \mathrm{~Hz}, 52 \mathrm{H}\right), 1.66-1.56(\mathrm{~m}, 104 \mathrm{H}), 1.48(\mathrm{~m}, 12 \mathrm{H}), 1.40-1.30(\mathrm{~m}, 52 \mathrm{H}), 0.94(\mathrm{t}$, $\left.{ }^{3} \mathrm{~J}(\mathrm{H}, \mathrm{H})=6.4 \mathrm{~Hz}\right) .{ }^{31} \mathrm{P}\left\{{ }^{1} \mathrm{H}\right\}$ NMR $\left(161.82 \mathrm{MHz}, \mathrm{CDCl}_{3}\right) ; \delta=33.3$. ATR-IR: $1105 \mathrm{~cm}^{-1}\left(\mathrm{~m}, \mathrm{CH}_{2}-\right.$ $\left.\mathrm{O}-\mathrm{CH}_{2}\right) ; 1190 \mathrm{~cm}^{-1}$ (m, $\left.\underline{O-C}=\mathrm{O}\right) ; 1720 \mathrm{~cm}^{-1}$ (s, C=O); $2800-2900 \mathrm{~cm}^{-1}$ (m, C-H).

Oct $_{3}$ P-BCP: ${ }^{1} \mathrm{H}$ NMR $\left(400 \mathrm{MHz}, \mathrm{CDCl}_{3}\right): \delta=7.72(\mathrm{~s}, 1 \mathrm{H}), 4.50\left(\mathrm{t},{ }^{3} \mathrm{~J}(\mathrm{H}, \mathrm{H})=5.2 \mathrm{~Hz}, 2 \mathrm{H}\right), 4.03$ $\left(\mathrm{t},{ }^{3} \mathrm{~J}(\mathrm{H}, \mathrm{H})=6.6 \mathrm{~Hz}, 52 \mathrm{H}\right), 3.61(\mathrm{~m}, 180 \mathrm{H}), 2.90(\mathrm{~m}, 2 \mathrm{H}), 2.65(\mathrm{~m}, 2 \mathrm{H}), 2.37(\mathrm{~m}, 8 \mathrm{H}), 2.27(\mathrm{t}$, $\left.{ }^{3} \mathrm{~J}(\mathrm{H}, \mathrm{H})=7.6 \mathrm{~Hz}, 52 \mathrm{H}\right), 1.66-1.56(\mathrm{~m}, 104 \mathrm{H}), 1.48(\mathrm{~m}, 12 \mathrm{H}), 1.40-1.30(\mathrm{~m}, 52 \mathrm{H}) ; 0.94(\mathrm{t}$, $\left.{ }^{3} \mathrm{~J}(\mathrm{H}, \mathrm{H})=6.4 \mathrm{~Hz}, 20 \mathrm{H}\right) .{ }^{31} \mathrm{P}\left\{{ }^{1} \mathrm{H}\right\} \mathrm{NMR}\left(161.82 \mathrm{MHz}, \mathrm{CDCl}_{3}\right) ; \delta=33.3$. ATR-IR: $1105 \mathrm{~cm}^{-1}(\mathrm{~m}$, $\left.\mathrm{CH}_{2}-\mathrm{O}-\mathrm{CH}_{2}\right) ; 1190 \mathrm{~cm}^{-1}$ (m, $\left.\underline{O-C}=\mathrm{O}\right) ; 1720 \mathrm{~cm}^{-1}$ (s, C=O);2800-2900 $\mathrm{cm}^{-1}$ (m, C-H).

\section{Self-assembly of block copolymers}

Copolymer $(5 \mathrm{mg})$ was dissolved in glass distilled THF $(0.5 \mathrm{~mL})$ that had been passed through a $0.22 \mu \mathrm{m}$ polytetrafluoroethylene filter. The copolymer solution was then added to rapidly stirring purified water $(2 \mathrm{~mL})$ that had been passed through an Acrodisc ${ }^{\circledR}$ Syringe Filter $(0.45 \mu \mathrm{m}$ 
Supor ${ }^{\circledR}$ Membrane) (Pall Life Sciences). The resulting suspension was placed in a $30{ }^{\circ} \mathrm{C}$ sand bath overnight to evaporate the THF.

\section{Transmission electron microscopy (TEM)}

TEM images were obtained using a Philips CM 10 Transmission Electron Microscope. Selfassembly samples were loaded onto Formvar-coated copper grids by placing the grid on a clean filter paper and dropping $10 \mu \mathrm{L}$ of a $0.5-1.0 \mathrm{mg} / \mathrm{mL}$ solution onto the grid, and repeating after 30 seconds. The grid was allowed to dry overnight on the filter paper and was imaged the next day. The $\mathbf{A l k}_{3} \mathbf{P}-\mathbf{B C P}$ nanocarriers were stained by adding $100 \mu \mathrm{L}$ of a $1 \mathrm{wt} \%$ aqueous auric acid solution to the stock TEM solution and allowing it to stir for one hour to exchange chloride anions with aurate. The sample was then loaded onto the grid as described above.

\section{Determination of the minimum bactericidal concentration (MBC)}

The bacteria used were E. coli (ATCC 29425) and S. aureus (ATCC 6538). After inoculation of $10 \mathrm{~mL}$ of $0.3 \mathrm{mM} \mathrm{pH} 7.4$ phosphate buffer, the bacteria were cultured overnight in an incubatorshaker at $37^{\circ} \mathrm{C}$. They were then pelletized by centrifugation and the broth was decanted. $10 \mathrm{~mL}$ of phosphate solution was then used to resuspend the pellet. The bacteria were again pelletized by centrifugation. This process of resuspension and centrifugation was repeated twice more. For S. aureus, a suspension with an optical density of 0.3 at $600 \mathrm{~nm}$, corresponding to $10^{7} \mathrm{CFU} / \mathrm{mL}$ was prepared. For E. coli, a suspension with an optical density of 0.2 at $600 \mathrm{~nm}$, corresponding to $10^{8} \mathrm{CFU} / \mathrm{mL}$ was prepared. These stock solutions were then diluted to $\sim 2 \times 10^{5} \mathrm{CFU} / \mathrm{mL}$. Samples for testing were prepared at the highest concentration for testing in $0.3 \mathrm{mM} \mathrm{pH}$ 7.4 phosphate buffer and serial two-fold dilutions were performed to achieve lower 
concentrations. All molecules and assemblies were sterilized by irradiation with UV light in a UV light cabinet for 30 minutes prior to testing. Tests were performed in 96 well plates. Sample wells contained $100 \mu \mathrm{L}$ of the sample material in phosphate buffer and $100 \mu \mathrm{L}$ of the bacterial suspension at $10^{5} \mathrm{CFU} / \mathrm{mL}$. Control wells contained $100 \mu \mathrm{L}$ of phosphate buffer and $100 \mu \mathrm{L}$ of the bacterial suspension at $10^{5} \mathrm{CFU} / \mathrm{mL}$. The phosphate buffer was also tested for sterility. Samples and controls were measured in triplicate. The wells were mixed for 4 hours at ambient temperature using a Tecan infinite M1000 Pro (Tecan Trading AG, Switzerland) plate reader. The suspensions were then diluted by adding $100 \mu \mathrm{L}$ of the well contents into $9.9 \mathrm{~mL}$ of phosphate buffer to give a resulting bacterial concentration of approximately $10^{3} \mathrm{CFU} / \mathrm{mL} .100$ $\mu \mathrm{L}$ of this suspension was then pour plated in nutrient agar and incubated overnight at $37^{\circ} \mathrm{C}$. The nutrient agar was prepared by dissolving $25 \mathrm{~g}$ of LB broth (Miller's modification) (Alfa Aesar, Reston, United States) and $15 \mathrm{~g}$ of Agar Powder $\left(\mathrm{C}_{12} \mathrm{H}_{18} \mathrm{O}_{9}\right)_{\mathrm{x}}$ (Alfa Aesar, Reston, United States) in $1 \mathrm{~L}$ of hot water $\left(85^{\circ} \mathrm{C}\right)$. The following day the bacterial colonies were counted. The MBC was determined as the concentration where no bacterial colonies were observed ( $>99 \%$ reduction in viability, based on $10^{2}$ CFUs plated). A summary of the concentrations tested and their corresponding results are includes in Tables S1 and S2.

\section{Hemolysis assay}

The hemolytic activity of the nanocarriers was determined using sterile defibrinated sheep's blood (Cedarlane Labs, Burlington Ontario, Canada). The blood was pelletized by centrifuging 1 $\mathrm{mL}$ of the blood and washing the pellet four times with $0.9 \%$ saline. The pellet was resuspended in $1 \mathrm{~mL}$ of a phosphate buffered saline (PBS) consisting of $0.32 \mathrm{mM} \mathrm{NaH}_{2} \mathrm{PO}_{4}$ and $140.40 \mathrm{mM}$ $\mathrm{NaCl}$ maintained at a $\mathrm{pH}$ of 7.4 to create the red blood cell (RBC) suspension. A concentrated 
solution of the micelles was diluted with $750 \mu \mathrm{L}$ of the PBS to the highest concentration for the assay. The micelle solutions were diluted two-fold serially with PBS to achieve the desired concentrations. To the micelle solutions $25 \mu \mathrm{L}$ of the RBC suspension was added. A negative control of $25 \mu \mathrm{L}$ of the RBC suspension in $1000 \mu \mathrm{L}$ of the PBS and a positive control of $25 \mu \mathrm{L}$ of the RBC suspension in $1000 \mu \mathrm{L}$ purified water. Nanocarrier background controls were made consisting of the same concentration of the nanocarrier in PBS to eliminate absorbance or scattering contributions from the nanocarriers themselves. The samples were incubated at room temperature for 2 hours and afterward the samples were centrifuged to re-pelletize the blood cells. $200 \mu \mathrm{L}$ of the supernatant of each sample and control were placed into wells in a 96 well plate and the absorbance (A) at $540 \mathrm{~nm}$ was measured. The percent hemolysis was determined with the following equation:

Percent Hemolysis $=\frac{A_{\text {sample }}-A_{\text {micelles }}-A_{\text {negative control }}}{A_{\text {positive control }}-A_{\text {negative control }}} \times 100 \%$

\section{Tetracycline encapsulation}

$500 \mu \mathrm{L}$ of a solution of tetracycline $\left(0.5 \mathrm{mg} / \mathrm{mL}\right.$ in $\left.\mathrm{CHCl}_{3}\right)$ was used to dissolve either MeO-

BCP or $\mathbf{B u}_{3} \mathbf{P}-\mathbf{B C P}(5 \mathrm{mg})$. With rapid stirring $2 \mathrm{~mL}$ of purified water was added and stirring was continued overnight at $30^{\circ} \mathrm{C}$. The sample was covered with aluminum foil to allow evaporation of $\mathrm{CHCl}_{3}$ while at the same time preventing exposure to ambient light. The resulting suspension was then introduced into a Microsep ${ }^{\mathrm{TM}}$ Advance Centrifugal Device with a $10 \mathrm{~kg} / \mathrm{mol}$ MWCO (Pall Life Sciences) and the solvent was reduced to 1/5 its initial volume. The concentrated suspension was diluted to $2 \mathrm{~mL}$ of purified water, and centrifugation was performed again. The filtrate was combined and the concentration of tetracycline in the filtrate was 
measured by UV-visible spectroscopy $\left(\varepsilon=14,075 \mathrm{M}^{-1} \mathrm{~cm}^{-1}\right.$ in water at $\left.363 \mathrm{~nm}\right)$ in order to determine the encapsulation efficiency (EE) of tetracycline as:

$\mathrm{EE}=\frac{\text { Mass of Drug in Particles }}{\text { Mass of Drug Added }} \times 100 \%$

The drug loading content (DLC) of the assemblies could then be calculated as:

$\mathrm{DLC}=\frac{\text { Mass of Drug in Particles }}{\text { Mass of Loaded Particles }} \times 100 \%$

\section{Tetracycline release study}

Assemblies containing encapsulated tetracycline were prepared as described above except that $0.3 \mathrm{mM}$, pH 7.2 phosphate buffer was used. A volume of $2 \mathrm{~mL}$ each of tetracycline-loaded MeO-BCP or $\mathbf{B u}_{3} \mathbf{P}-\mathbf{B C P}$ micelles was then placed on a wrist-action shaker. At measurement time points, centrifugal ultrafiltration was performed as described above to separate released tetracycline from the suspension and the concentrated suspension was diluted again to $2 \mathrm{~mL}$ with the phosphate buffer. The absorbance of the filtrate was measured and the concentration of tetracycline in the filtrate was determined based on an $\varepsilon=14,075 \mathrm{M}^{-1} \mathrm{~cm}^{-1}$ in the same buffer at $363 \mathrm{~nm}$.

\section{Results and Discussion}

\section{Synthesis of PEO-b-PCL copolymers}

PEO- $b$-PCL copolymers were selected because of their established biocompatibility and low toxicity in drug delivery applications. ${ }^{39}$ An azide terminal group on the PEO was selected for the conjugation of the phosphonium moiety via a copper-assisted azide-alkyne cycloaddition (CuAAC). Methoxy- and azide-terminated PEO- $b$-PCL copolymers, $\mathbf{M e O - B C P}$ and $\mathbf{N}_{\mathbf{3}}-\mathbf{B C P}$ 
respectively, were synthesized according to our previously reported procedure. ${ }^{38}$ MeO-PEO or $\mathbf{N}_{3}$-PEO were used as macroinitiators to polymerize caprolactone in toluene using methanesulfonic acid (MSA) as a catalyst (Scheme 1). ${ }^{38}$ This method yields copolymers with very low molar mass dispersity $(\bigoplus)$. Low $Ð$ is important for good control over the morphology of the self-assemblies. ${ }^{40}$ From previous research it is known that a mass ratio of PCL:PEO of 1.3:1 yields micellar nanocarriers. ${ }^{41}$ Therefore, using a PEO macroinitiator of $\sim 2000 \mathrm{~g} / \mathrm{mol}$, a degree of polymerization (DP) of $\sim 24$ caprolactone repeat units was targeted. The resulting block copolymers were characterized by NMR spectroscopy and SEC. ${ }^{1}$ H NMR spectroscopy confirmed that the DPs were $\sim 24$ for each of MeO-BCP and $\mathbf{N}_{3}-\mathbf{B C P}$, corresponding to an $\mathrm{M}_{\mathrm{n}}$ of $\sim 4700 \mathrm{~g} / \mathrm{mol}$ (Figure S1-S2). By SEC relative to PEO standards, MeO-BCP had a number average molar mass $\left(\mathrm{M}_{\mathrm{n}}\right)$ of $5750 \mathrm{~g} / \mathrm{mol}$ and $€$ of 1.11 , while $\mathbf{N}_{\mathbf{3}}-\mathbf{B C P}$ had an $\mathrm{M}_{\mathrm{n}}$ of $5950 \mathrm{~g} / \mathrm{mol}$ and $Ð$ of 1.12 (Figure S3). The differences in $M_{n}$ of these copolymers measured by SEC likely arose from their different terminal groups.
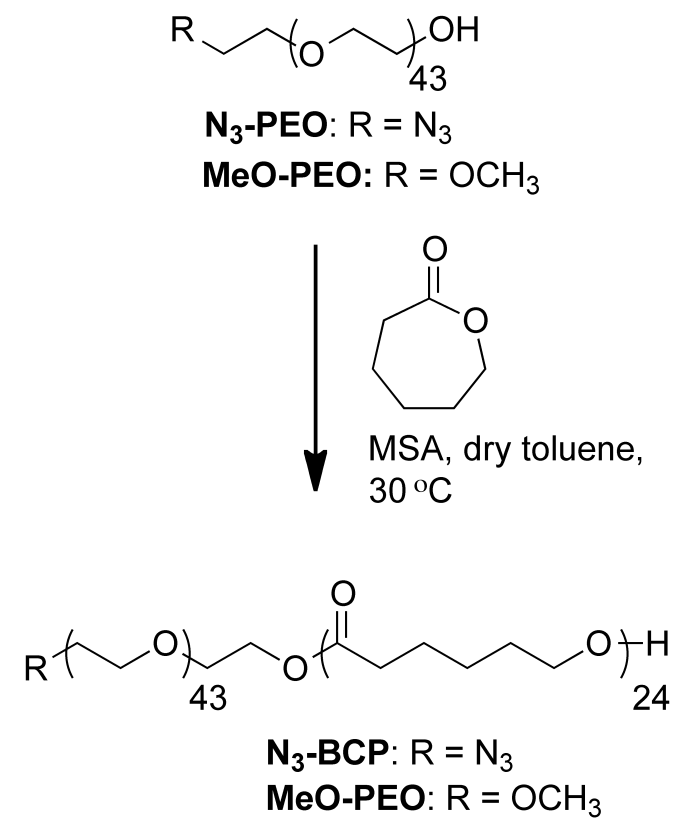

Scheme 1. Synthesis of MeO-BCP and $\mathbf{N}_{3}-\mathbf{B C P}$. 


\section{Synthesis of alkyne-functionalized phosphonium salts}

Alkyne-functionalized phosphonium centres were required for conjugation to $\mathbf{N}_{3}-\mathbf{B C P}$. The lengths of the alkyl chains on phosphonium and ammonium salts are known to affect the antibacterial activity of the small molecules, ${ }^{32}$ so it was desirable to explore this in the context of phosphonium-functionalized polymer assemblies. Initial attempts to prepare the alkynefunctionalized phosphonium salts by reaction of trialkylphosphines with propargyl bromide resulted in complex and inseparable product mixtures. This is due to side reactivity of the phosphonium salt with the unreacted phosphine. ${ }^{42}$ While addition of hydrobromic acid to the reaction reduced the number of products, isolation of the desired product remained elusive. On the other hand, use of 5-chloro-1-pentyne led to the conversion of triethylphosphine and tri- $n$ butylphosphine into single products $\mathbf{E t}_{\mathbf{3}} \mathbf{P}$-yne and $\mathbf{B} \mathbf{u}_{3} \mathbf{P}-\mathbf{y n e}$, respectively (Scheme 2). The synthesis of $\mathbf{O c t}{ }_{3} \mathbf{P}-\mathbf{y n e}$ yielded a mixture of products and silica gel column chromatography was used for purification. This was attributed to the extended heating time required to convert the starting material into product as this phosphine is more sterically hindered. In each case, the pure product was characterized by multinuclear magnetic resonance spectroscopy and high resolution mass spectrometry. The products showed characteristic peaks corresponding to both the alkyne and alkyl chains around the phosphonium cation (Figure 2). 

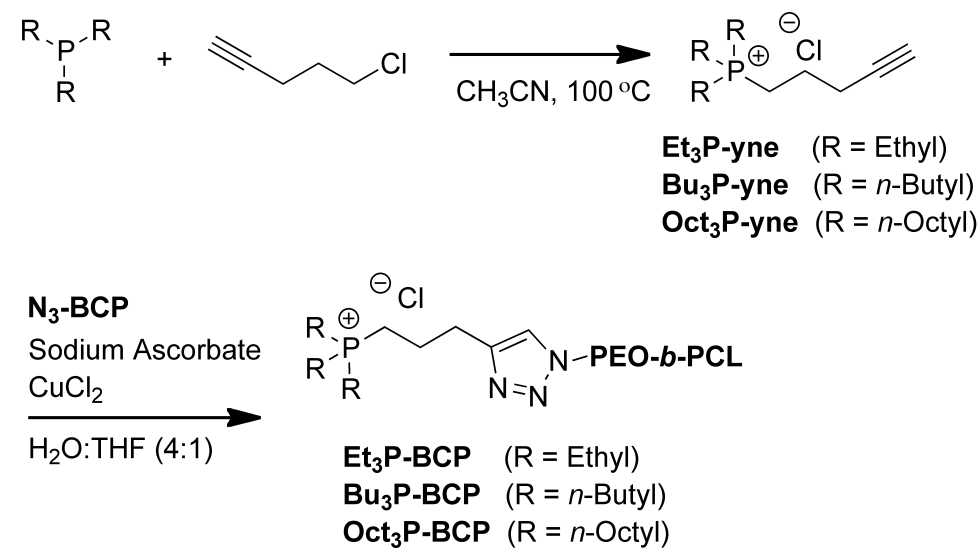

Scheme 2. Synthesis of the phosphonium salts and the phosphonium capped polymers.

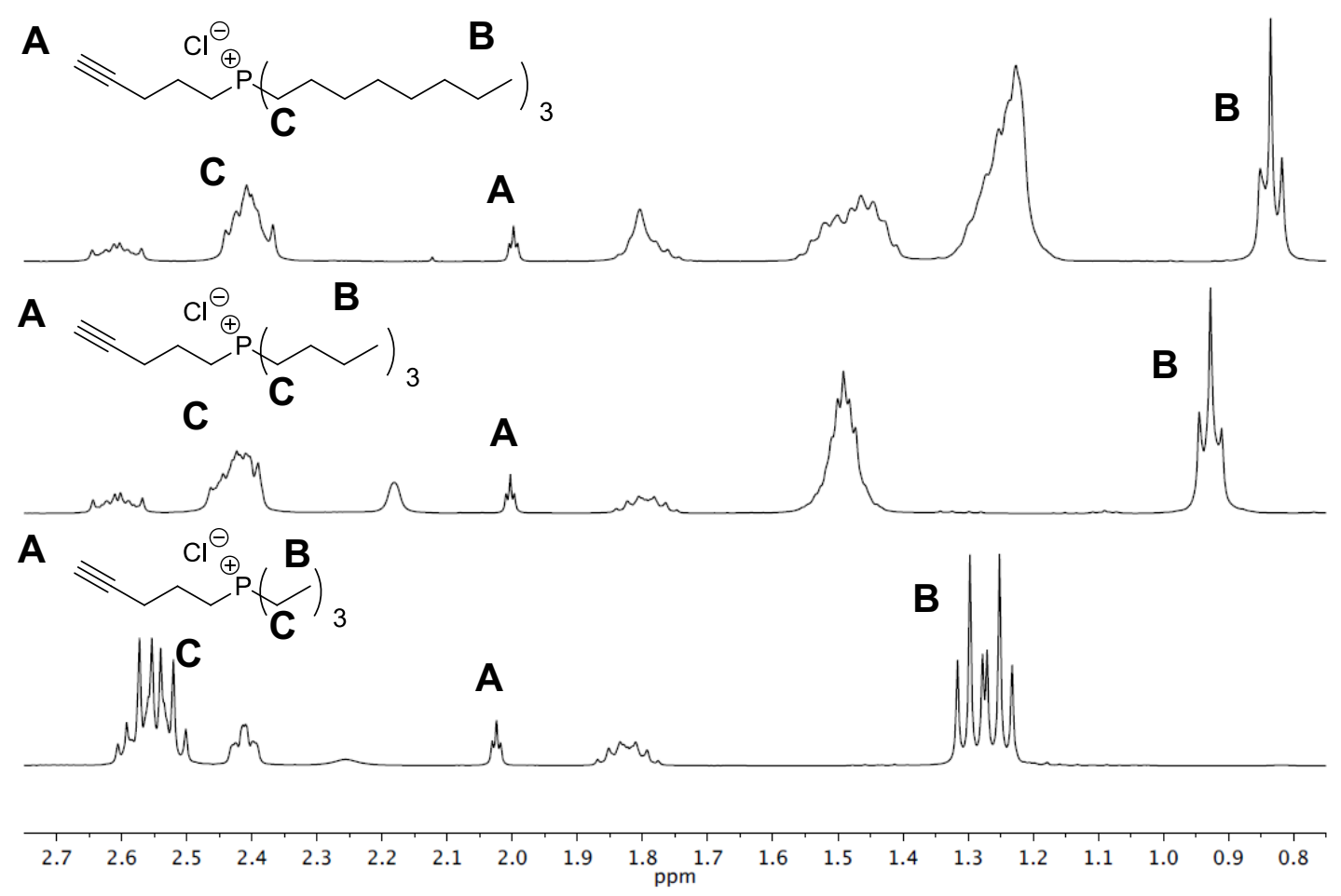

Figure 2. ${ }^{1} \mathrm{H} \mathrm{NMR}$ spectra $\left(\mathrm{CDCl}_{3}, 400 \mathrm{MHz}\right)$ of the phosphonium salts with selected peaks labeled.

Conjugation of the phosphonium cations to the block copolymers 
Attachment of the phosphonium salts to $\mathbf{N}_{\mathbf{3}}$-BCP was achieved using CuAAC in 4:1 $\mathrm{H}_{2} \mathrm{O}$ :THF with $\mathrm{CuCl}_{2}$ and sodium ascorbate to afford $\mathbf{E t} \mathbf{t}_{\mathbf{3}} \mathbf{P}-\mathbf{B C P}, \mathbf{B u}_{3} \mathbf{P}-\mathbf{B C P}$, and $\mathbf{O c t}_{3} \mathbf{P}-\mathbf{B C P}$ (Scheme 2). Due to the onwards use of the polymer in anti-bacterial testing it was imperative that any residual copper be removed from the functionalized materials. The reaction mixtures were therefore dialyzed against large volumes of $0.5 \mathrm{M} \mathrm{NaCl}$ solution, followed by water. The dialysis against aqueous $\mathrm{NaCl}$ was important to ensure that the phosphonium counterion remained chloride as there are reports in the literature that ascorbate may show antibacterial activity, thus we needed to preclude the chance of anion exchange. ${ }^{43}$ As shown in Figure 3 and S9-S10, IR spectra of the initial $\mathbf{N}_{\mathbf{3}}$-BCP showed strong azide stretches at $2100 \mathrm{~cm}^{-1}$, whereas this peak was no longer detectable beyond the background noise for the conjugated phosphonium products. Integration of the ${ }^{1} \mathrm{H}$ NMR signals corresponding to the methyl protons on the phosphonium groups relative to the terminal methylene group of the PEO block adjacent to the first repeat unit of the PCL block were consistent with complete conversion of the azides (Figure S11-S13). Peaks characteristic of the proton on the triazole ring were also observed in the ${ }^{1} \mathrm{H}$ NMR spectra of the phosphonium functionalized polymers.




Figure 3. ATR-IR spectra of the starting $\mathbf{N}_{\mathbf{3}}-\mathbf{B C P}$ (blue spectrum) and $\mathbf{B} \mathbf{u}_{\mathbf{3}} \mathbf{P}-\mathbf{B C P}$ (orange spectrum) showing the disappearance of the azide stretch following the CuAAC reaction.

\section{Micelle preparation and characterization}

The micelles were prepared from MeO-BCP, $\mathbf{E t}_{\mathbf{3}} \mathbf{P}-\mathbf{B C P}, \mathbf{B u}_{3} \mathbf{P}-\mathbf{B C P}$, and $\mathbf{O c t}_{\mathbf{3}} \mathbf{P}-\mathbf{B C P}$ by nanoprecipitation of a polymer solution in THF into water, which is a selective solvent for the PEO block of the copolymers. The rapid decrease in solubility of the PCL block in the solvent mixture causes the polymers to precipitate into nano-sized cores surrounded by PEO. Figures 4 A-D show representative TEM images of the resulting assemblies. Assemblies prepared from the phosphonium cation-capped polymers were stained using auric acid (Figure 4B-D). In this case,

the aurate can undergo anion exchange to bind to the positively charged phosphonium ion. ${ }^{44}$ In each case, solid spherical particles were observed. The sub-50 nm diameters of the MeO-BCP, $\mathbf{E t}_{\mathbf{3}} \mathbf{P}-\mathbf{B C P}$, and $\mathbf{B \mathbf { u } _ { 3 }} \mathbf{P}-\mathbf{B C P}$ assemblies suggests that they were largely true micellar structures, whereas some larger $50-100 \mathrm{~nm}$ assemblies were observed for $\mathbf{O c t}_{\mathbf{3}} \mathbf{P}-\mathbf{B C P}$, suggesting that some compound micelles or aggregates of micelles were also present. The $\mathbf{O c t}_{\mathbf{3}} \mathbf{P}-\mathbf{y n e}$ is not soluble in water and so installation of this hydrophobic end group on the hydrophilic block may cause this aggregation. 


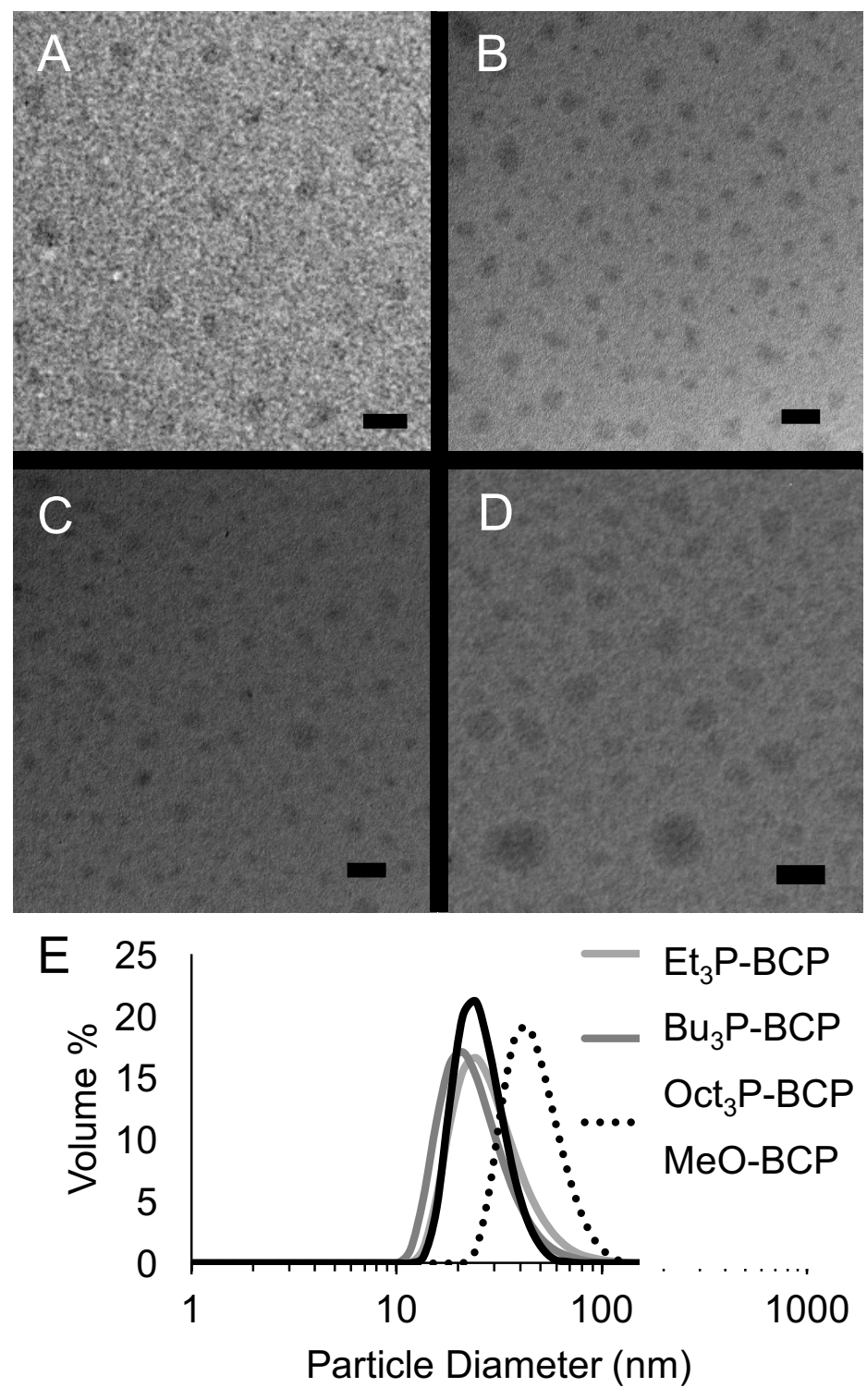

Figure 4. A - D) TEM micrographs of the assemblies prepared by nanoprecipitation (scale bar represents 100 nm): A) MeO-BCP micelles, B) $\mathbf{E} \mathbf{t}_{\mathbf{3}} \mathbf{P}-\mathbf{B C P}$ micelles, C) $\mathbf{B \mathbf { u } _ { 3 }} \mathbf{P}-\mathbf{B C P}$ micelles, D) Oct $_{3} \mathbf{P}-\mathbf{B C P}$ assemblies. All Alk $\mathbf{3}$ P-BCP samples (B-D) were stained with auric acid. E) Volume distributions of the assembly diameters measured by DLS.

As shown in Figure 4E and Table 1, the hydrodynamic diameters measured by dynamic light scattering (DLS) were in good agreement with the sizes observed by TEM. MeO-BCP 
micelles had a Z-average diameter of $\sim 30 \mathrm{~nm}$, while $\mathbf{E t}_{3} \mathbf{P}-\mathbf{B C P}$, and $\mathbf{B} \mathbf{u}_{3} \mathbf{P}-\mathbf{B C P}$ micelles had similar Z-average diameters of $40-45 \mathrm{~nm}$. The larger diameters of these phosphoniumfunctionalized micelles relative to the MeO-BCP micelles may result from repulsive electrostatic interactions between the peripheral phosphoniums. Oct ${ }_{3} \mathbf{P}-\mathbf{B C P}$ assemblies had a larger Z-average diameter of $59 \mathrm{~nm}$ due to the presence of compound micelles or aggregates as noted above. $\zeta$-potentials of the micelles were also measured. MeO-BCP micelles had a $\zeta$ potential of $-23 \mathrm{mV}$. This is typical for assemblies with PEO coronas. ${ }^{45}$ On the other hand, all of the phosphonium-functionalized micelles had positive $\zeta$-potentials and these ranged from 19 to $30 \mathrm{mV}$. This confirms that the phosphonium cations reside on the surface of the micelles. Interestingly, the value of the $\zeta$-potential increased with the length of the alkyl chain on the phosphonium center. This was somewhat unexpected as the more hydrophobic phosphonium cations could be buried within the PEO corona. However, the results reveal that this may not be the case and the cause of the observed trend in not clear at this time.

Table 1. Hydrodynamic diameters and $\zeta$-potentials measured for the polymer assemblies by dynamic light scattering.

\begin{tabular}{|l|l|l|l|}
\hline & $\begin{array}{l}\text { Z-average } \\
\text { diameter }(\mathrm{nm})\end{array}$ & $\begin{array}{l}\text { Polydispersity index } \\
(\mathrm{PDI})\end{array}$ & $\begin{array}{l}\zeta \text {-potential } \\
(\mathrm{mV})\end{array}$ \\
\hline MeO-BCP micelles & $29.5 \pm 0.8$ & $0.122 \pm 0.027$ & $-23.2 \pm 5.2$ \\
\hline $\mathbf{E t}_{3} \mathbf{P}-\mathbf{B C P}$ micelles & $45.0 \pm 2.5$ & $0.072 \pm 0.003$ & $19.0 \pm 2.4$ \\
\hline $\mathbf{B u}_{3} \mathbf{P}-\mathbf{B C P}$ micelles & $39.6 \pm 3.7$ & $0.213 \pm 0.025$ & $26.8 \pm 7.7$ \\
\hline Oct 3 P-BCP assemblies & $58.9 \pm 2.8$ & $0.110 \pm 0.020$ & $29.7 \pm 0.5$ \\
\hline
\end{tabular}




\section{Antibacterial properties of phosphonium-functionalized assemblies}

The antibacterial efficacies of the phosphonium-functionalized micelles and their corresponding small molecule phosphonium salts were evaluated by measuring their minimum bactericidal concentrations $(\mathrm{MBC})$. The $\mathrm{MBC}$ is the concentration required to kill $99 \%$ of bacteria in the assay. This assay involved inoculating varying concentrations of the assemblies or small molecules in $\mathrm{pH} 7.4$ phosphate buffer with a bacterial suspension containing $10^{5}$ colony forming units (CFU)/mL of either Gram-negative E. coli (ATCC 29425) or Gram-positive S. aureus (ATCC 6538). The inoculated samples were incubated at $37^{\circ} \mathrm{C}$ for 4 hours, then the resulting suspensions were plated on agar, incubated overnight and then the bacterial colonies were counted. The percent reduction, and thus $\mathrm{MBC}$, was calculated by comparing the number of colonies counted after incubation with the sample compared to those of bacteria exposed to only phosphate buffer with no polymer or small molecule added.

As shown in Table 2, the small molecule phosphonium cations had relatively high MBC values against both $E$. coli and $S$. aureus. It was not possible to test $\mathbf{O c t}_{\mathbf{3}} \mathbf{P}$-yne due to its poor aqueous solubility, but $\mathbf{E t}_{3} \mathbf{P}$-yne had a MBC greater than $45 \mathrm{mM}$, the highest concentration tested, against $S$. aureus than $E$. coli. $\mathbf{B} \mathbf{u}_{3} \mathbf{P}$-yne was more active, with $\mathrm{MBC}$ values of $4.1 \mathrm{mM}$ and $33 \mathrm{mM}$ for $S$. aureus than E. coli, respectively. MeO-BCP micelles were also studied and the $\mathrm{MBC}$ was found to be greater than $1.1 \mathrm{mM}$ in terms of polymer chain concentration for both strains of bacteria, the highest concentration tested. Thus, the block copolymers themselves are not antibacterial. On the other hand, the phosphonium-functionalized assemblies all had much lower MBCs than the small molecules, demonstrating the importance of having a multivalent display of cations. Interestingly there was no observed difference in $\mathrm{MBC}$ between the $\mathbf{E} \mathbf{t}_{\mathbf{3}} \mathbf{P}$ BCP micelles and $\mathbf{B u}_{3} \mathbf{P}-\mathbf{B C P}$ micelles with $S$. aureus $(0.13 \mathrm{mM}$ for both systems), but there was 
with $E$. coli $\left(0.26 \mathrm{mM}\right.$ and $0.13 \mathrm{mM}$, respectively). The $\mathbf{O c t}_{3} \mathbf{P}-\mathbf{B C P}$ assemblies had the greatest activity against $S$. aureus with an MBC of $0.031 \mathrm{mM}$, while they had the highest MBC of the phosphonium-functionalized assemblies against $E$. coli at $0.49 \mathrm{mM}$.

Table 2. MBC values for the phosphonium salts and phosphonium-functionalized assemblies against $S$. aureus and E. coli. For the block copolymers, the concentrations correspond to the concentrations of polymer chains, and thus the concentration of the terminal phosphonium groups.

\begin{tabular}{|c|c|c|}
\hline Compound & $\begin{array}{c}\text { MBC against } \\
\text { S. aureus } \\
\text { (mM) }\end{array}$ & $\begin{array}{c}\text { MBC against } \\
\text { E. coli } \\
\text { (mM) }\end{array}$ \\
\hline Et $_{3}$ P-yne & $>45$ & $>45$ \\
\hline $\mathrm{Bu}_{3} \mathrm{P}$-yne & 4.1 & 32.8 \\
\hline $\begin{array}{c}\text { MeO-BCP } \\
\text { micelles }\end{array}$ & $>1.1$ & $>1.1$ \\
\hline $\begin{array}{c}\mathrm{Et}_{3} \mathrm{P}-\mathrm{BCP} \\
\text { micelles }\end{array}$ & 0.13 & 0.26 \\
\hline $\begin{array}{c}\mathrm{Bu}_{3} \mathrm{P}-\mathrm{BCP} \\
\text { micelles }\end{array}$ & 0.13 & 0.13 \\
\hline $\begin{array}{c}\text { Oct }_{3} \mathrm{P}-\mathrm{BCP} \\
\text { micelles }\end{array}$ & 0.031 & 0.49 \\
\hline
\end{tabular}

With the exception of $\mathbf{B} \mathbf{u}_{3} \mathbf{P}-\mathbf{B C P}$ micelles, higher MBC values were found for $E$. coli. The lower efficacy against $E$. coli was expected based on previous research, and can likely be 
attributed to differences in the cell wall structures of Gram-positive and Gram-negative bacteria. ${ }^{46}$ Gram-positive bacteria such as $S$. aureus have a plasma membrane surrounded by a periplasmic space and a peptidoglycan layer, whereas Gram-negative bacteria such as E. coli have an additional outer membrane surrounding the peptidoglycan layer. The mode of action of monocationic and polycationic biocides is generally accepted to include the following processes: 1) Biocide adsorption to the cell surface, 2) biocide diffusion through the cell wall, 3) adsorption to the cytoplasmic membrane, 4) cytoplasmic membrane disruption, and 5) loss of cytoplasmic components, resulting in cell death. ${ }^{31}$ Gram-negative bacteria have an additional barrier through which the biocide must diffuse, and disrupt, which may explain why higher concentrations of micelles were generally required to kill E. coli.

It was also noted that different trends with respect to alkyl chain length were observed for the different strains of bacteria as $\mathbf{O c t}_{3} \mathbf{P}-\mathbf{B C P}$ micelles had the lowest MBC for $S$. aureus, whereas $\mathbf{B} \mathbf{u}_{3} \mathbf{P}-\mathbf{B C P}$ micelles had the lowest MBC for $E$. coli. While phosphonium groups with longer alkyl chains have been previously demonstrated to show greater antibacterial activity in genera ${ }^{34}$ there is also data to suggest that the relationship between alkyl chain length and antibacterial efficacy is not linear and in some cases lower activity has been observed with increased alkyl chain length. ${ }^{47}$ As hydrophilic cationic groups promote attachment to bacterial membrane and hydrophobic alkyl chains insert into membranes to disrupt them, the hydrophilicity and hydrophobicity must be balanced to match the requirements of the different bacterial membranes. ${ }^{48}$ It is also possible that the larger size of the $\mathbf{O c t}_{3} \mathbf{P}-\mathbf{B C P}$ assemblies plays a role. The larger size of the individual assemblies results in fewer particles for a given polymer/phosphonium concentration and thus fewer assemblies and less surface area to interact with the bacteria. ${ }^{49}$ In comparing the small molecule cationic biocides with polycationic 
biocides, the small molecules typically have higher rates of diffusion through the cell wall, while the multivalent nature of polycationic biocides increases the adsorption to the cell surface and the cytoplasmic membrane, often leading to increased rates and occurrences of cytoplasmic membrane disruption. ${ }^{31}$

The phosphonium-functionalized assemblies can also be compared with other antibacterial polymer assemblies. For example, Du and co-workers demonstrated the preparation of silver nanoparticle-decorated micelles and vesicles with antibacterial activity. ${ }^{21}$ These assemblies had a low MBC of $8.69 \times 10^{-2} \mathrm{mM}$ of Ag. However, it is unclear whether the activity of the system arose from nano-silver associated with the micelles or dissociated $\mathrm{Ag}^{+}$ions released into solution that were not associated with the micellar corona. ${ }^{21}$ The mechanism of bacterial killing by nano-silver, while controversial, ${ }^{50}$ is also different and is thought to involve the inactivation of the bacterial DNA and ribosomes by silver ions. ${ }^{51,52}$ Later, the same group reported the preparation of antibacterial nanoassemblies composed of poly[2-(2methoxyethoxy)ethyl methacrylate $]_{20}$-block-poly[2-(tert-butylaminoethyl) methacrylate $]_{20}{ }^{26}$ The polyamine block ionizes in solution to give positively charged particles. Vesicles prepared from the above polymer were reported to have $\mathrm{MBC}$ values of $0.63 \mathrm{mM}$ of amine against both $E$. coli and $S$. aureus. ${ }^{26}$ Later, multicompartment polymer vesicles prepared from the same polymers were reported to have improved antibacterial efficacy with $\mathrm{MBC}$ values of $0.1 \mathrm{mg} / \mathrm{mL}$ or $1.27 \mathrm{x}$ $10^{-2} \mathrm{mM}$ of amine, a value lower than their measured minimum inhibitory concentration (MIC) values for the same material. ${ }^{27}$ As the MIC corresponds to the concentration required to inhibit bacterial growth but not necessary kill the bacteria, MIC values are not generally expected to be higher than $\mathrm{MBC}$ values. However, this discrepancy may be due to differences in the testing methods. Du and coworkers also reported that low MIC values in the $\mu \mathrm{M}$ range could be 
achieved against $E$. coli and $S$. aureus using polypeptides as the hydrophilic block of a vesicle forming polymeric amphiphile. ${ }^{53}$

\section{Hemolysis of red blood cells}

A challenge often encountered with membrane-active antibacterial agents is that in addition to lysing bacterial cell membranes, they can also lyse the membranes of red blood cells, resulting in non-specific toxicity. Therefore, to evaluate the potential of the phosphonium-functionalized micelles to lyse red blood cells, a hemolysis assay was performed. Briefly, following a previously reported procedure, ${ }^{54}$ red blood cells were obtained from defibrinated sheep blood and were incubated with MeO-BCP, Et $\mathbf{t}_{3} \mathbf{P}-\mathbf{B C P}, \mathbf{B u}_{3} \mathbf{P}-\mathbf{B C P}, \mathbf{O c t}_{\mathbf{3}} \mathbf{P}-\mathbf{B C P}$ micelles in PBS for 2 hours. As a positive control, red blood cells were suspended in deionized water, resulting in the immediate lysis of the cells. The absorbance of the supernatant at $540 \mathrm{~nm}$ after pelletization of the intact blood cells was measured. As shown in Figure 5, only $0.53 \mathrm{mM}$ of $\mathbf{E t}_{\mathbf{3}} \mathbf{P}$-BCP micelles exhibited any hemolytic activity, with 7\% hemolysis observed. Interestingly, this particular system was the least active of the 3 systems against both strains of bacteria, so this result was unexpected. While there is not a complete understanding of all the factors influencing selectivity for eukaryotic and prokaryotic membranes, ${ }^{46}$ it is likely that the particular hydrophilichydrophobic balance of the $\mathbf{E t}_{\mathbf{3}} \mathbf{P}-\mathbf{B C P}$ micelles results in its higher activity against red blood cell membranes. ${ }^{55}$ Nevertheless, the overall results suggest that the phosphonium-functionalized micelles have good potential to selectively kill bacteria. While further studies would be required to elucidate the in vitro and in vivo toxicity, previous studies have shown that phosphonium compounds can exhibit low in vitro, ${ }^{36,56}$ and in vivo ${ }^{56}$ toxicity. 


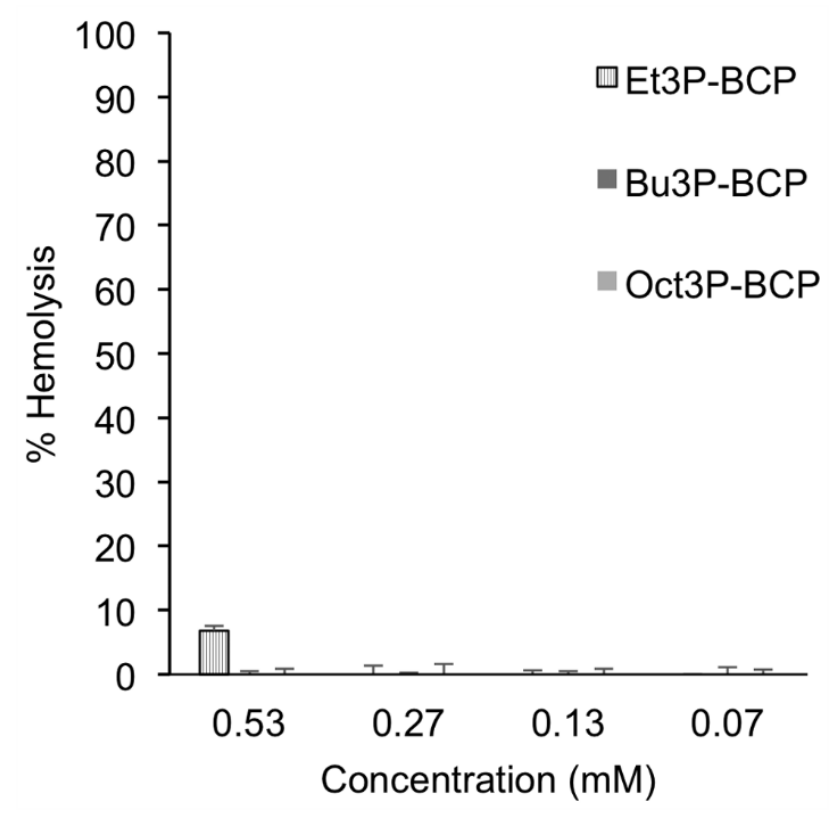

Figure 5. Hemolysis of red blood cells from defribinated sheep blood. 0\% hemolysis corresponds to the control of red blood cells in PBS while $100 \%$ hemolysis corresponds to the positive control of red blood cells in purified water.

\section{Encapsulation and release of tetracycline}

The antibacterial efficacy of the phosphonium-functionalized assemblies can potentially be enhanced through encapsulation of a small molecule antibiotic that acts through a mechanism other than membrane disruption, thereby targeting multiple different stages of the infection process. Such an approach has not been explored in the context of antibacterial polymer assemblies to the best of our knowledge. Tetracycline (Figure 6) was chosen as the antibiotic as it is widely used and is hydrophobic, resulting in low aqueous solubility and the possibility to encapsulate it in the hydrophobic PCL cores of the micelles. Tetracycline acts by binding to the bacterial ribosome and preventing the production of new proteins. ${ }^{57}$ It was encapsulated in the micelles through co-dissolution with the polymer in $\mathrm{CHCl}_{3}$, followed by the addition of water with rapid stirring and heating at $30{ }^{\circ} \mathrm{C}$ overnight to evaporate the $\mathrm{CHCl}_{3}$. Unencapsulated drug 
was then removed by centrifugal ultrafiltration (Figure S14). This procedure was performed for both MeO-BCP and $\mathbf{B u}_{3} \mathbf{P}-\mathbf{B C P}$ in order to determine the effect of the phosphonium moieties on the drug loading and release. This afforded assemblies with diameters of $65 \pm 5 \mathrm{~nm}$ for MeOBCP as measured by DLS (Figure S15). The amount of drug loaded into the assemblies was determined as the difference between the drug added during assembly and the unencapsulated drug removed by ultrafiltration, which was determined by UV-vis spectroscopy. The EE and DLC were determined to be $31 \pm 7 \%$ and $2.0 \pm 0.2 \%$ for MeO-BCP and, $42 \pm 3 \%$ and $3.1 \pm$ $0.3 \%$ for $\mathbf{B u}_{\mathbf{3}} \mathbf{P}-\mathbf{B C P}$ respectively. The higher EE and DLC observed in the $\mathbf{B} \mathbf{u}_{\mathbf{3}} \mathbf{P}-\mathbf{B C P}$ system may result from ionic interactions between the anionic tetracycline and the cationic phosphonium ions on the micelles.

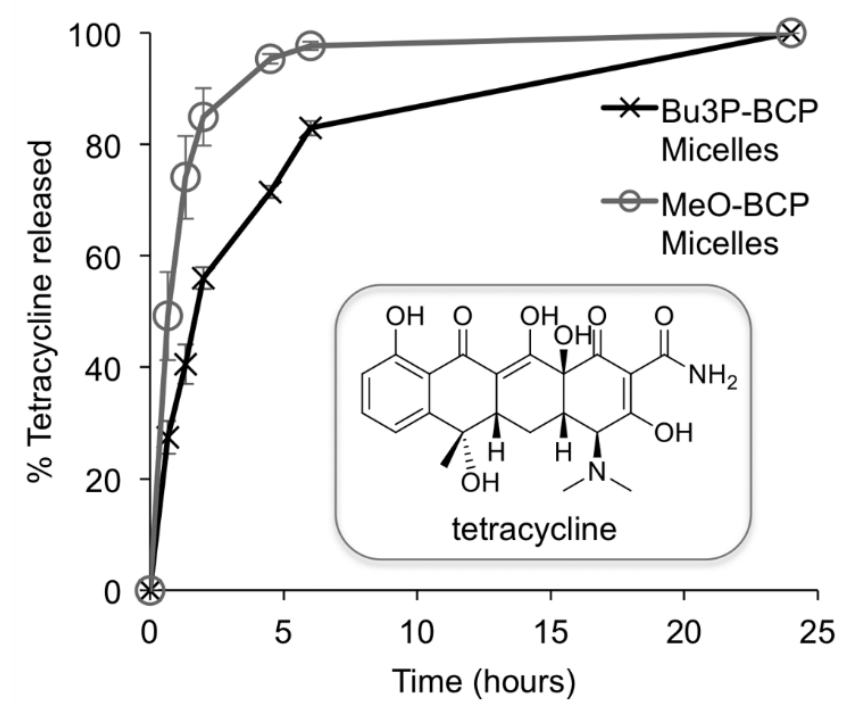

Figure 6. Release profiles of tetracycline from $\mathrm{MeO}-\mathrm{BCP}$ micelles and $\mathrm{Bu}_{3} \mathbf{P}-\mathbf{B C P}$ micelles. Inset: tetracycline structure

The release rate of tetracycline from the $\mathbf{M e O}-\mathbf{B C P}$ and $\mathbf{B u}_{3} \mathbf{P}-\mathbf{B C P}$ micelles was then studied by incubating the drug-loaded micelles at $37^{\circ} \mathrm{C}$ in $\mathrm{pH} 7.2$ phosphate buffer. At each time 
point, centrifugal ultrafiltration was used to separate the micelles from the released drug and the concentration of the released drug was measured. As shown in Figure 6, all of the encapsulated tetracycline was released from the MeO-BCP micelles in $\sim 5$ hours. The release of tetracycline was somewhat slower from the $\mathbf{B \mathbf { u } _ { 3 }} \mathbf{P}-\mathbf{B C P}$ micelles, with $\sim 70 \%$ of the drug being released over the first $5 \mathrm{~h}$ and $100 \%$ release over $24 \mathrm{~h}$. The differences in release rates between the two systems is likely due to the presence of the phosphonium end cap. Upon release from the hydrophobic micelle core into the phosphate buffer, tetracycline's vinylogous carboxylic acid may become deprotonated and undergo ionic interactions with the phosphonium cations on the surfaces of the micelle, thereby slowing its release.

Antibacterial assays with $E$. coli were performed to examine the added effect of the tetracycline in the micelle core. It was found that at the tetracycline loadings described above, the activity of the $\mathbf{B u _ { 3 }} \mathbf{P}-\mathbf{B C P}$ micelles was dominated by the phosphonium groups and the same MBC value was determined. No activity was observed for tetracycline-loaded MeO-BCP micelles over a 4 hour incubation at a concentration of $0.26 \mathrm{mM}$ of polymer. This can be attributed to the bacteriostatic effects of tetracycline. On the time scale of the experiment, the tetracycline would not kill bacteria but instead just inhibit its ability to produce new proteins. ${ }^{58}$ Thus, these experiments were not able to reveal an additive or synergistic effect of the drug and phosphonium on the bacteria. However, this does not preclude the possibility of observing one in vivo where the released drug could exhibit significantly different biodistribution than the assemblies and may reach sites not accessible to the polymer assemblies. Further studies will be needed to investigate this possibility.

\section{Conclusions}


In conclusion, this study demonstrated the synthesis and self-assembly of three new phosphonium-functionalized PEO-b-PCL copolymers with varying alkyl chain lengths on the phosphonium. $\mathbf{E t}_{3} \mathbf{P}-\mathbf{B C P}, \mathbf{B u}_{3} \mathbf{P}-\mathbf{B C P}$, and the control MeO-BCP self-assembled into micelles with diameters less than $50 \mathrm{~nm}$, while $\mathbf{O c t}_{3} \mathbf{P}-\mathbf{B C P}$ formed larger micelles or aggregates. All of the phosphonium-functionalized assemblies had positive $\zeta$-potentials, whereas the MeO-BCP micelles had a negative $\zeta$-potentials. Despite relatively low loadings of the antibacterial component (only a single phosphonium unit per polymer chain), sub-mM MBC values were obtained against both E. coli and S. aureus and the activities of the different systems depended on the bacterial stain due to differences in their cell wall structures. In comparing the MBC values for the assemblies with those of the corresponding phosphonium small molecules, the assemblies were much more effective in killing bacteria, presumably due to their multivalent interactions with the bacteria. The low loadings of the phosphonium groups on the assemblies also allowed then to exhibit excellent hemolytic stability, with only the highest concentration of $\mathbf{E t}_{3} \mathbf{P}-\mathbf{B C P}$ micelles showing any hemolytic activity, above the MBC for both $S$. aureus and $E$. coli. It was also demonstrated that the intrinsically antibacterial $\mathbf{B} \mathbf{u}_{3} \mathbf{P}-\mathbf{B C P}$ micelles could encapsulate and release tetracycline, providing the potential for an orthogonal mechanism of attack against bacteria during the infection process. Future work will involve further optimization of the system and as well as further exploration of the multifunctional capabilities of these micelles.

\section{Supporting information}

${ }^{1} \mathrm{H}$ NMR, ${ }^{13} \mathrm{C}$ NMR and ${ }^{31} \mathrm{P}$ NMR, and ATR-IR spectra, SEC traces, additional antibacterial testing data, image of the centrifugal ultrafiltration device, additional DLS data. 


\section{Acknowledgements}

The authors thank the Natural Science and Engineering Council of Canada Discovery Grant Program and the University of Western Ontario for funding this work and Solvay-Cytec in providing useful starting materials. The authors would also like to thank Tyler Cuthbert for his assistance with bacterial work.

\section{Notes}

The authors declare no competing financial interest.

\section{References}

(1) Chen, G.; Roy, I.; Yang, C.; Prasad, P. N. Nanochemistry and Nanomedicine for Nanoparticle-based Diagnostics and Therapy. Chem. Rev. 2016, 116, 2826-2885.

(2) Mura, S.; Nicolas, J.; Couvreur, P. Stimuli-responsive Nanocarriers for Drug Delivery. Nat. Mater. 2013, 12, 991-1003.

(3) Kamaly, N.; Yameen, B.; Wu, J.; Farokhzad, O. C. Degradable Controlled-Release Polymers and Polymeric Nanoparticles: Mechanisms of Controlling Drug Release. Chem. Rev. 2016, 116, 2602-2663.

(4) Duncan, R. The Dawning Era of Polymer Therapeutics. Nat. Rev. Drug Discov. 2003, 2, $347-360$.

(5) Hamley, I. Block Copolymers in Solution: Fundamentals and Applications; John Wiley and Sons, 2012.

(6) Kim, Y.; Dalhaimer, P.; Christian, D. A.; Discher, D. E. Polymeric Worm Micelles as 
Nano-carriers for Drug Delivery. Nanotechnology 2005, 16, S484-S491.

(7) Truong, N. P.; Quinn, J. F.; Whittaker, M. R.; Davis, T. P. Polymeric Filomicelles and Nanoworms: Two Decades of Synthesis and Application. Polym. Chem. 2016, 7, 42954312.

(8) Mane, S. R.; Rao N, V.; Chaterjee, K.; Dinda, H.; Nag, S.; Kishore, A.; Das Sarma, J.; Shunmugam, R. Amphiphilic Homopolymer Vesicles as Unique Nano-carriers for Cancer Therapy. Macromolecules 2012, 45, 8037-8042.

(9) Wieczorek, S.; Dallmann, A.; Kochovski, Z.; Börner, H. G. Advancing Drug Formulation Additives toward Precision Additives with Release Mediating Peptide Interlayer. J. Am. Chem. Soc. 2016, 138, 9349-9352.

(10) Rösler, A.; Vandermeulen, G. W. M.; Klok, H.-A. Advanced Drug Delivery Devices via Self-assembly of Amphiphilic Block Copolymers. Adv. Drug Delivery Rev. 2012, 64, $270-279$.

(11) Mai, Y.; Eisenberg, A. Self-assembly of Block Copolymers. Chem. Soc. Rev. 2012, 41, $5969-5985$.

(12) Gao, P.; Nie, X.; Zou, M.; Shi, Y.; Cheng, G. Recent Advances in Materials for Extendedrelease Antibiotic Delivery System. J. Antibiot. 2011, 64, 625-634.

(13) World Health Organization. WHO | Global action plan on antimicrobial resistance http://www.who.int/drugresistance/global_action_plan/en/(accessed Jun 14, 2016).

(14) Moreno-Sastre, M.; Pastor, M.; Salomon, C. J.; Esquisabel, A.; Pedraz, J. L. Pulmonary Drug Delivery: A Review on Nanocarriers for Antibacterial Chemotherapy. J. Antimicrob. Chemother. 2015, 70, 2945-2955.

(15) Maya, S.; Indulekha, S.; Sukhithasri, V.; Smitha, K. T.; Nair, S. V.; Jayakumar, R.; 
Biswas, R. Efficacy of Tetracycline Encapsulated $O$-Carboxymethyl Chitosan Nanoparticles Against Intracellular Infections of Staphylococcus aureus. Int. J. Biol. Macromol. 2012, 51, 392-399.

(16) Li, Y.; Liu, G.; Wang, X.; Hu, J.; Liu, S. Enzyme-Responsive Polymeric Vesicles for Bacterial-Strain-Selective Delivery of Antimicrobial Agents. Angew. Chem. Int. Ed. 2016, $55,1760-1764$.

(17) Liu, Y.; Busscher, H. J.; Zhao, B.; Li, Y.; Zhang, Z.; van der Mei, H. C.; Ren, Y.; Shi, L. Surface-Adaptive, Antimicrobially Loaded, Micellar Nanocarriers with Enhanced Penetration and Killing Efficiency in Staphylococcal Biofilms. ACS Nano 2016, 10, 4779_ 4789.

(18) Zhang, L.; Gu, F. X.; Chan, J. M.; Wang, A. Z.; Langer, R. S.; Farokhzad, O. C. Nanoparticles in Medicine: Therapeutic Applications and Developments. Clin. Pharmacol. Ther. 2008, 83, 761-769.

(19) Rösler, A.; Vandermeulen, G. W. M.; Klok, H. A. Advanced Drug Delivery Devices via Self-assembly of Amphiphilic Block Copolymers. Adv. Drug Delivery Rev. 2012, 64, $270-279$.

(20) Torchilin, V. P. Multifunctional nanocarriers. Adv. Drug Deliv. Rev. 2012, 64, 302-315.

(21) Lu, H.; Fan, L.; Liu, Q.; Wei, J.; Ren, T.; Du, J. Preparation of Water-dispersible Silverdecorated Polymer Vesicles and Micelles with Excellent Antibacterial Efficacy. Polym. Chem. 2012, 3, 2217.

(22) Zou, K.; Liu, Q.; Chen, J.; Du, J. Silver-decorated Biodegradable Polymer Vesicles with Excellent Antibacterial Efficacy. Polym. Chem. 2014, 5, 405-411.

(23) Sun, H.; Fan, L.; Zou, K.; Zhu, H.; Du, J. Decoration of Homopolymer Vesicles by 
Antibacterial Ultrafine Silver Nanoparticles. RSC Adv. 2014, 4, 41331-41335.

(24)

Zhou, C.; Wang, M.; Zou, K.; Chen, J.; Zhu, Y.; Du, J. Rationally Engineering Dual

Missions in One Statistical Copolymer Nanocapsule: Bacterial Inhibition and Polycyclic Aromatic Hydrocarbon Capturing. ACS Macro Lett. 2013, 2, 1021-1025.

(25) Shi, Z.; Neoh, K. G.; Kang, E. T.; Wang, W. Antibacterial and Mechanical Properties of Bone Cement Impregnated with Chitosan Nanoparticles. Biomaterials 2006, 27, 24402449.

(26) Zhang, C.; Zhu, Y.; Zhou, C.; Yuan, W.; Du, J. Antibacterial Vesicles by Direct Dissolution of a Block Copolymer in Water. Polym. Chem. 2013, 4, 255-259.

(27) Zhu, H. S.; Geng, Q. R.; Chen, W. Q.; Zhu, Y. Q.; Chen, J.; Du, J. Antibacterial Highgenus Polymer Vesicle as an "Armed" Drug Carrier. J. Mater. Chem. B 2013, 1, 54965504.

(28) Li, Y.; Hu, X.; Tian, S.; Li, Y.; Zhang, G.; Zhang, G.; Liu, S. Polyion Complex Micellar Nanoparticles for Integrated Fluorometric Detection and Bacteria Inhibition in Aqueous Media. Biomaterials 2014, 35, 1618-1626.

(29) Carmona-Ribeiro, A. M.; de Melo Carrasco, L. D. Cationic Antimicrobial Polymers and Their Assemblies. Int. J. Mol. Sci. 2013, 14, 9906-9946.

(30) Siedenbiedel, F.; Tiller, J. C. Antimicrobial Polymers in Solution and on Surfaces: Overview and Functional Principles. Polymers 2012, 4, 46-71.

(31) Kenawy, E.-R.; Worley, S. D.; Broughton, R. Antimicrobial Polymers in Solution and on Surfaces: Overview and Functional Principles. Biomacromolecules 2007, 8, 1359-1384.

(32) Kanazawa, A.; Ikeda, T.; Endo, T. Novel Polycationic Biocides. Synthesis and Antibacterial Activity of Polymeric Phosphonium Salts. J. Polym. Sci., Part A: Polym. 
Chem. 1993, 31, 335-343.

(33) Kanazawa, A.; Ikeda, T.; Endo, T. Polymeric Phosphonium Salts as a Novel Class of Cationic Biocides. II. Effects of Counter Anion and Molecular Weight on Antibacterial Activity of Polymeric Phosphonium Salts. J. Polym. Sci., Part A: Polym. Chem. 1993, 31, $1441-1447$.

(34) Kanazawa, A.; Ikeda, T.; Endo, T. Polymeric Phosphonium Salts as a Novel Class of Cationic Biocides. IV. Synthesis and Antibacterial Activity of Polymers with Phosphonium Salts in the Main Chain. J. Polym. Sci., Part A: Polym. Chem. 1993, 31, $3031-3038$.

(35) Cuthbert, T. J.; Harrison, T. D.; Ragogna, P. J.; Gillies, E. R. Synthesis, Properties, and Antibacterial Activity of Polyphosphonium Semi-interpenetrating Networks. J. Mater. Chem. B 2016, 4, 4872-4883.

(36) Cuthbert, T. J.; Guterman, R.; Ragogna, P. J.; Gillies, E. R. Contact Active Antibacterial Phosphonium Coatings Cured with UV light. J. Mater. Chem. B 2015, 3, 1474-1478.

(37) Park, S.; Cha, S. H.; Cho, I.; Park, S.; Park, Y.; Cho, S.; Park, Y. Antibacterial Nanocarriers of Resveratrol with Gold and Silver Nanoparticles. Mater. Sci. Eng. C 2016, $58,1160-1169$.

(38) Puskas, J. E.; Sen, M. Y.; Kasper, J. R. Green Polymer Chemistry: Telechelic Poly(ethylene glycol)s via Enzymatic Catalysis. J. Polym. Sci., Part A: Polym. Chem. 2008, 46, 3024-3028.

(39) Sinha, V. R.; Bansal, K.; Kaushik, R.; Kumria, R.; Trehan, A. Poly-e-caprolactone Microspheres and Nanospheres: An Overview. Int. J. Pharm. 2004, 278, 1-23.

(40) Mai, Y.; Eisenberg, A. Self-assembly of Block Copolymers. Chem. Soc. Rev. 2012, 41, 
5969.

(41) Nazemi, A.; Amos, R. C.; Bonduelle, C. V.; Gillies, E. R. Dendritic Surface

Functionalization of Biodegradable Polymer Assemblies. J. Polym. Sci., Part A: Polym.

Chem. 2011, 49, 2546-2559.

(42) Davies, J. H.; Kirby, P. The Prototropic Isomerization of Unsaturated Organophosphorus Compounds. J. Chem. Soc. 1964, 3425-3429.

(43) Tajkarimi, M.; Ibrahim, S. A. Antimicrobial Activity of Ascorbic Acid Alone or in Combination with Lactic Acid on Escherichia coli O157:H7 in Laboratory Medium and Carrot Juice. Food Control 2011, 22, 801-804.

(44) Hadadpour, M.; Gwyther, J.; Manners, I.; Ragogna, P. J. Multifunctional Block Copolymer: Where Polymetallic and Polyelectrolyte Blocks Meet. Chem. Mater. 2015, $27,3430-3440$.

(45) Fang, C.; Shi, B.; Pei, Y.-Y.; Hong, M.-H.; Wu, J.; Chen, H.-Z. In Vivo Tumor Targeting of Tumor Necrosis Factor- $\alpha$-loaded Stealth Nanoparticles: Effect of MePEG Molecular Weight and Particle Size. Eur. J. Pharm. Sci. 2006, 27, 27-36.

(46) Timofeeva, L.; Kleshcheva, N. Antimicrobial polymers: Mechanism of Action, Factors of Activity, and Applications. Appl. Microbiol. Biotechnol. 2011, 89, 475-492.

(47) Panarin, E. F.; Solovskii, M. V.; Zaikina, N. A.; Afinogenov, G. E. Biological Activity of Cationic Polyelectrolytes. Makromol. Chemie, Suppl. 1985, 9, 25-33.

(48) Chen, A.; Peng, H.; Blakey, I.; Whittaker, A. K. Biocidal Polymers: A Mechanistic Overview. Polym. Rev. 2016, 1-35.

(49) Lu, H.; Fan, L.; Liu, Q.; Wei, J.; Ren, T.; Du, J. Preparation of Water-dispersible Silverdecorated Polymer Vesicles and Micelles with Excellent Antibacterial Efficacy. Polym. 
Chem. 2012, 3, 2217-2227.

(50) Sotiriou, G. A.; Pratsinis, S. E. Antibacterial Activity of Nanosilver Ions and Particles. Environ. Sci. Technol. 2010, 44, 5649-5654.

(51) Feng, Q. L.; Wu, J.; Chen, G. Q.; Cui, F. Z.; Kim, T. N.; Kim, J. O. A Mechanistic Study of the Antibacterial Effect of Silver Ions on Escherichia coli and Staphylococcus aureus. J. Biomed. Mater. Res. 2000, 52, 662-668.

(52) Yamanaka, M.; Hara, K.; Kudo, J. Bactericidal Actions of a Silver Ion Solution on Escherichia coli, Studied by Energy-filtering Transmission Electron Microscopy and Proteomic Analysis. Appl. Environ. Microbiol. 2005, 71, 7589-7593.

(53) Wang, M.; Zhou, C.; Chen, J.; Xiao, Y.; Du, J. Multifunctional Biocompatible and Biodegradable Folic Acid Conjugated Poly( $\varepsilon$-caprolactone)-polypeptide Copolymer Vesicles with Excellent Antibacterial Activities. Bioconjugate Chem. 2015, 26, 725-734.

(54) Abd-El-Aziz, A. S.; Agatemor, C.; Etkin, N.; Overy, D. P.; Lanteigne, M.; McQuillan, K.; Kerr, R. G. Antimicrobial Organometallic Dendrimers with Tunable Activity against Multidrug-Resistant Bacteria. Biomacromolecules 2015, 16, 3694-3703.

(55) Sambhy, V.; Peterson, B. R.; Sen, A. Antibacterial and Hemolytic Activities of Pyridinium Polymers as a Function of the Spatial Relationship Between the Positive Charge and the Pendant Alkyl Tail. Angew. Chem. Int. Ed. 2008, 47, 1250-1254.

(56) O’Toole, G. A.; Wathier, M.; Zegans, M. E.; Shanks, R. M. Q.; Kowalski, R.; Grinstaff, M. W. Diphosphonium Ionic Liquids as Broad-spectrum Antimicrobial Agents. Cornea 2012, 31, 810-816.

(57) Chopra, I.; Roberts, M. Tetracycline Antibiotics: Mode of Action, Applications, Molecular Biology, and Epidemiology of Bacterial Resistance. Microbiol. Mol. Biol. Rev. 
2001, 65, 232-260. 
Table of contents graphic



Intrinsically

Antibacterial

Nanocarrier 